\title{
Monitoring and detection of the swede midge (Diptera: Cecidomyilidae)
}

\author{
Rebecca H. Hallett, ${ }^{1}$ Sheila A. Goodfellow, James D. Heal \\ Department of Environmental Biology, University of Guelph, \\ Guelph, Ontario, Canada N1G 2W1
}

\begin{abstract}
In 2002, two types of light traps were compared against sticky yellow cards for efficiency and selectivity in capturing adult swede midge Contarinia nasturtii (Kieffer) (Diptera: Cecidomyiidae). Incandescent light traps were more efficient at capturing swede midge than were sticky traps. Incandescent light traps were more selective than blacklight traps and required less time for processing of samples and identification of captured midges. Emergence (2003 and 2004) and pheromone (2004) traps were used to assess swede midge population dynamics. Captures from emergence traps indicate up to five overlapping emergence events for swede midge each year. Emergence traps captured swede midge earlier in the season than pheromone traps, but pheromone-trap captures continued later in the season than those in emergence traps. Pheromone traps are small and portable, easy to maintain, and capture significantly more swede midge than emergence traps.
\end{abstract}

\begin{abstract}
Résumé-En 2002, nous avons comparé l'efficacité et la sélectivité de deux types de pièges lumineux à celles des pièges à carte collante jaune pour la capture des cécidomyies du chou-fleur adultes Contarinia nasturtii (Kieffer) (Diptera : Cecidomyiidae). Les pièges à lumière incandescente capturent plus efficacement la cécidomyie du chou-fleur que les pièges collants. Les pièges à lumière incandescente sont plus sélectifs que les pièges à lumière ultraviolette; ils requièrent moins de temps pour le traitement des échantillons et l'identification des cécidomyies capturées. Nous avons utilisé des pièges d'émergence (2003 et 2004) et des pièges à phéromones (2004) pour déterminer la dynamique de population des cécidomyies. Les captures dans les pièges d'émergence indiquent l'existence de jusqu'à cinq épisodes d'émergence qui se chevauchent chaque année chez les cécidomyies du chou-fleur. Les pièges d'émergence capturent les cécidomyies du chou-fleur plus tôt dans la saison que les pièges à phéromones, mais les captures au pièges à phéromones se prolongent plus tard dans la saison que celles faites aux pièges d'émergence. Les pièges à phéromones sont petits, portatifs et faciles à entretenir et ils capturent significativement plus de cécidomyies du chou-fleur que les pièges d'émergence.
\end{abstract}

[Traduit par la Rédaction]

\section{Introduction}

The presence of the swede midge, Contarinia nasturtii (Kieffer) (Diptera: Cecidomyiidae), in Canada was first determined in 2000 (Hallett and Heal 2001). The swede midge is considered to be a minor pest of Brassica L. spp. (Brassicaceae) in Europe (Hill 1987) but a quarantine pest in North America (Canadian Food Inspection Agency 2002; United States Department of Agriculture 2002). The Canadian Food Inspection Agency (2002) has determined that the swede midge represents a moderate level of overall risk with a high potential for a negative economic impact in
Canada. Where population levels are high, complete loss of marketable yield can occur.

The adult swede midge is a small lightbrown fly, 1-2 mm long, with very hairy wings (Barnes 1946). Mature larvae are 3-4 mm long and lemon-yellow in colour. Host plants include Brassica spp. and allied cruciferous crops (Barnes 1946). Females will oviposit on tender young tissue on host plants of any developmental stage (i.e., from the seedling stage to flowering). Eggs are laid in groups on young leaves, near meristematic tissue, and in unopened flower buds (Readshaw 1961). Larvae generally

Received 23 August 2005. Accepted 12 April 2007.

${ }^{1}$ Corresponding author (e-mail: rhallett@uoguelph.ca). 
remain protected within the compact, central leaves of their host plants. Larval feeding on epidermal cells causes scarring, deformation of plant tissue, and death of meristematic tissue, leading to reductions in both yield and marketability of produce.

At the time that the swede midge was first determined to be present in Ontario, it was known from only a few isolated sites, and a retrospective examination of sticky yellow cards at two sites revealed only very low midge captures despite high levels of infestation (Hallett and Heal 2001). Consequently, we were interested in developing more effective methods for capturing the swede midge and assessing its population dynamics in Ontario.

\section{Materials and methods}

\section{Efficiency and selectivity of light traps and sticky yellow cards}

Three trap types (incandescent light, black light, and sticky yellow card) were set out within rows in mixed cole crop fields at three sites (Table 1) in Ontario in late August and early September 2002 in a randomized complete block design, where blocks were replicates, with five replicates per site. The Markham $\left(43^{\circ} 54^{\prime} \mathrm{N}, 79^{\circ}\right.$ $\left.22^{\prime} \mathrm{W}\right)$ and Hillsburgh $\left(43^{\circ} 49^{\prime} \mathrm{N}, 80^{\circ} 10^{\prime} \mathrm{W}\right)$ sites were approximately 10 and $60 \mathrm{~km}$ west of the Stouffville $\left(43^{\circ} 58^{\prime} \mathrm{N}, 7^{\circ} 16^{\prime} \mathrm{W}\right)$ site, respectively. CDC Miniature Light Traps and CDC Downdraft Blacklight Traps (model Nos. 512 and 912, respectively; John W. Hock Company, Gainesville, Florida, United States of America) were fitted by the supplier with either a CM47 6.3 V incandescent bulb or a $4 \mathrm{~W}$ fluorescent black-light phosphor with blue filtering glass (F4T/BLB; Sylvania Blacklight Blue, Osram Sylvania, Danvers, Massachusetts, United States of America). Light traps and double-sided sticky yellow cards were attached to wooden stakes $95 \mathrm{~cm}$ above the ground. Traps within a replicate were separated by $4.6 \mathrm{~m}$ and replicates by $24 \mathrm{~m}$, except at Hillsburgh, where distances were 3.7 and $8.0 \mathrm{~m}$, respectively, because of space constraints. Sticky yellow cards were left in fields for 1 week; light traps were set up in fields on the 4th night of the same week about $1 \mathrm{~h}$ before sunset and dismantled $15 \mathrm{~h}$ later. The effective trapping period was $11 \mathrm{~h}$ (sunset to sunrise) for light traps and $168 \mathrm{~h}$ for sticky traps. Maximum-minimum thermometers were placed at each site to record minimum temperatures during the light-trapping period.
All traps and (or) trap contents were examined in the laboratory. All arthropods captured were first separated by order. All members of Diptera were then sorted according to suborder, and all possible swede midge specimens ("swede midge-like" nematocerans) were isolated. All potential swede midge specimens were examined under the microscope to separate them from other individuals. Swede midge specimens were positively identified according to descriptions by Harris (1966), and male genitalia were compared to figures therein.

Statistical analyses were performed using SAS $^{\circledR}$ (SAS Institute Inc. 2001). Trap efficiency was examined by subjecting swede midge capture data to square-root transformation followed by analysis of variance (ANOVA) using PROC GLM (SAS Institute Inc. 2001), with the model statement capture $=$ trap site replicate(site) trap $\times$ site. The assumptions of ANOVA were verified using PROC UNIVARIATE prior to analyses. Means separations were performed using Tukey's Studentized range (HSD) tests with $\alpha=0.05$.

Selectivity of incandescent and black-light traps was compared using ANOVA for captures of Diptera as a proportion of total arthropods captured, for captures of swede midge as a proportion of total nematocerans captured, and for captures of swede midge as a proportion of total swede midge-like individuals captured, following verification of the assumptions of ANOVA. Proportional data were subjected to arcsine square root transformations prior to ANOVA (Bowley 1999), with the model statement capture $=$ trap site replicate (site) trap $x$ site. A single data point was removed from analyses of captures of swede midge as a proportion of total swede midge-like individuals because no individuals in this category were captured in one incandescent trap at Hillsburgh. As a result of a significant trap type by site effect, trap selectivity in terms of captures of swede midge as a proportion of total swede midge-like individuals was analysed separately for each site, with the model statement capture = trap replicate trap $\times$ replicate. Means separations were performed using Tukey's Studentized range (HSD) tests with $\alpha=0.05$. Untransformed means are presented unless otherwise indicated.

\section{Comparison of pheromone and emergence traps}

Emergence tent traps based on the Marshall raised emergence trap trap design (Marshall and 
Table 1. Temperature and environmental (solar and lunar) parameters during the light-trapping period in a trap design experiment at three sites in August-September 2002.

\begin{tabular}{lcccccc}
\hline Site & Dates & Min. temp. & Sunset & Sunrise & Moonrise & Phase of moon \\
\hline Stouffville & 23-28 Aug. & $10^{\circ} \mathrm{C}$ & 1956 & 0646 & 2226 & Gibbous waning \\
Hillsburgh & 30 Aug. - 4 Sept. & $14^{\circ} \mathrm{C}$ & 1952 & 0652 & 0316 & Waning crescent \\
Markham & 6-10 Sept. & $13^{\circ} \mathrm{C}$ & 1936 & 0656 & 0949 & Waxing crescent \\
\hline
\end{tabular}

Cui 2005) (Fig. 1) were constructed from nosee-um mesh (Venture Textiles, Braintree, Massachusetts, United States of America), and used to assess emergence events at two field sites (Markham and Stouffville) with known infestations of swede midge in 2003 and 2004.

On 10 May 2003, 10 emergence traps at each field site were erected over bare soil (plot $\mathrm{A}$ ) in an area known to have had a high incidence of swede midge in previous years. As there were no host plants in these plots, swede midge captures from plot A consisted exclusively of the overwintered population. The edges of all emergence traps were buried in the soil. Broccoli (Brassica oleracea var. italica L. 'Paragon') plants were transplanted into three sequentially planted plots, each having five rows of 30 plants, with $65 \mathrm{~cm}$ between-row spacing and $45 \mathrm{~cm}$ within-row spacing, on 5 June (plot B), 18 July (plot C), and 21 August (plot D). Owing to constraints on emergence-trap numbers, the emergence traps were relocated to new plots as the season progressed. When late-instar larvae were present on plants in plot B (24 June), emergence traps were moved into the plot and each covered two infested broccoli plants. On 30 August, when larvae on infested plants in plot $C$ were mature, emergence traps were moved to plot C. Plants in plot D did not become infested, so no traps were established in that plot. Capture jars were replaced daily from 10 May to 10 October 2003, and contents were examined for swede midge.

On 28 April 2004, six emergence traps each at the Markham and Stouffville sites were placed over bare soil (plot $\mathrm{A}$ ) in an area known to have had a high incidence of swede midge in previous years. Site design in 2004 was the same as in 2003, except that broccoli plants were planted in rows of 20 plants with $65 \mathrm{~cm}$ between-row spacing and $45 \mathrm{~cm}$ within-row spacing. Transplanting dates were 19 May (plot B), 30 June (plot C), 2 August (plot D) and 1 September (plot E). Four emergence traps, each erected over two swede midge-infested broccoli plants, were set up in plot B when late-instar larvae were found on plants (28 June). Because of constraints on emergence-trap numbers, the traps were relocated to new plots as the season progressed. On 28 July and 27 August, emergence traps were moved to plots $C$ and $D$, respectively. Plot E did not become infested, so no traps were established in that plot. Capture jars were replaced 3 times a week until 20 October 2004 and contents were examined for swede midge.

A three-component pheromone lure consisting of a cotton-wick dispenser treated with a 1:2:0.02 blend of $(2 S, 9 S)$-diacetoxyundecane, $(2 S, 10 S)$ diacetoxyundecane, and (S)-2-acetoxyundecane (Hillbur et al. 2005) became available for experimentation in 2004 and allowed a comparison to be made between emergence and pheromone traps. The pheromone dispenser was suspended inside a brown waxed cardboard delta trap $(22.5 \mathrm{~cm} \times$ $11 \mathrm{~cm}$ sides, $22.5 \mathrm{~cm} \times 9.5 \mathrm{~cm}$ base) (provided by Drs. R. Baur and S. Rauscher, Agroscope, Wadenswil, Switzerland), which was attached to a wooden stake at a height of $30 \mathrm{~cm}$ with a bulldog clip. A sticky white insert $(15.5 \mathrm{~cm} \times 9.0 \mathrm{~cm})$ coated with Tangle-Trap ${ }^{\circledR}$ insect trap coating (The Tanglefoot Company, Grand Rapids, Michigan, United States of America) was placed inside the base of the delta trap to capture insects entering the trap.

At each site, three pheromone traps were placed $45^{\circ}$ to each other, $35 \mathrm{~m}$ from the center of the plot covered by emergence traps (to avoid trap interference) on 10 May 2004. Trap inserts were changed 3 times a week and each pheromone dispenser was replaced every 28 days with half of the dispensers being replaced every 2 weeks. Delta traps were replaced every 8 weeks. Trap inserts were returned to the University of Guelph and examined for the presence of swede midge.

Plots of cumulative trap captures were used to determine when emergence events peaked; with this method an abrupt increase in the steepness of the slope of the line indicates when a peak emergence event occurred. In late July and August, the timing of peak emergence events was determined by examining both daily and cumulative trap captures. 
Fig. 1. Emergence tent trap used for monitoring emergence of adult swede midge (Contarinia nasturtii) from the soil between May and October in 2003 and 2004.

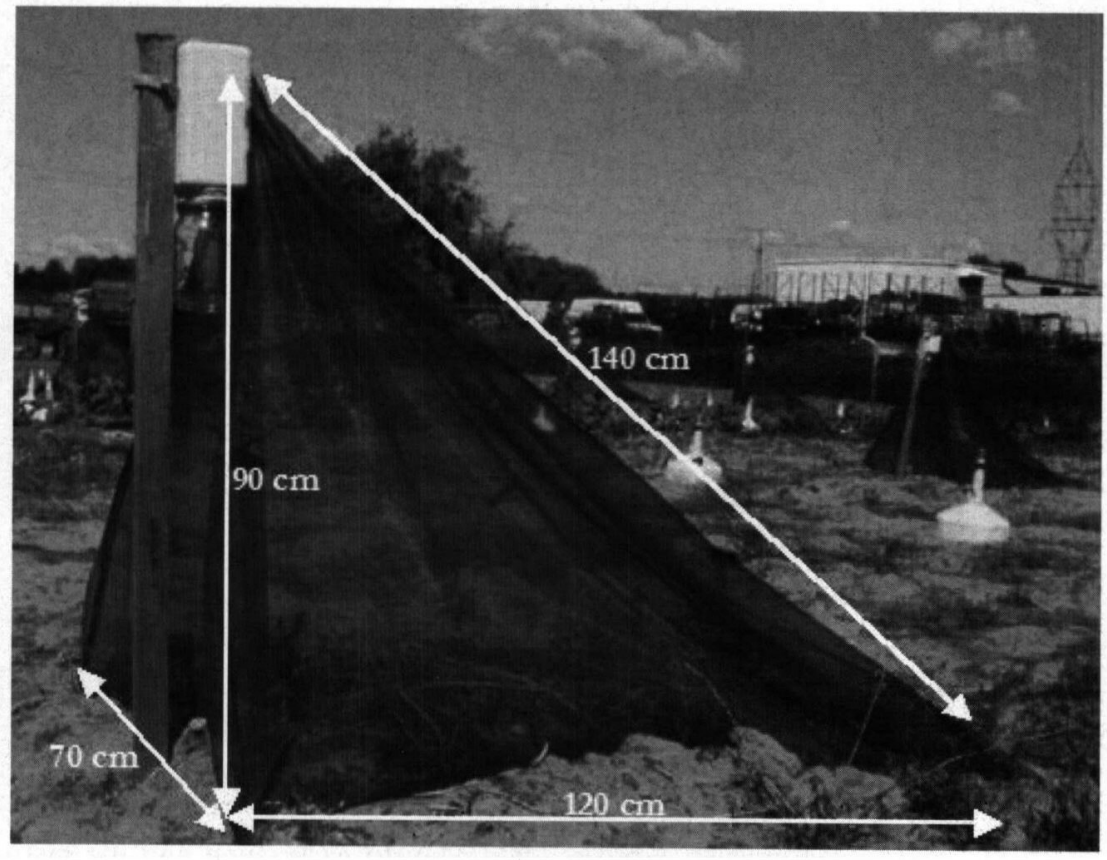

Statistical analyses were performed using SAS $^{\circledR}$ (SAS Institute Inc. 2001). Non-parametric methods were used to compare emergence- and pheromone-trap captures in 2004, as assumptions underlying ANOVA (Bowley 1999) were not met. A comparison between emergence and pheromone traps was made for the total number of adult swede midge caught per trap over the entire season for each site. Only data from emergence traps that were in the field for the entire season (i.e., six per site) were used in these analyses. To determine if there were unequal variances between the two trapping types, a Kolmogorov-Smirnov test was utilized. As the variances of the two samples were not equal, a Welch's test was performed to determine if total swede midge captures per trap differed between emergence and pheromone traps.

\section{Results}

\section{Efficiency and selectivity of light traps and sticky yellow cards}

At each site, only a single adult swede midge was captured on any of the sticky yellow cards during the 7 day sticky-trapping period. Analysis of swede midge captures (model: $F_{11,33}=$ 3.38, $P<0.004, n=45$ ) revealed statistically significant differences for the main effects of trap type $\left(F_{2,33}=6.67, P<0.004\right)$, site $\left(F_{2,33}=\right.$ 4.50, $P<0.02)$, and replicate $\left(F_{3,33}=3.77, P<\right.$ 0.02 ), but no significant trap type by site interaction was observed $\left(F_{4,33}=0.89, P>0.48\right)$. Incandescent light traps captured significantly more swede midge than sticky traps (Fig. 2).

Analysis of Diptera captured as a proportion of total arthropods captured (model: $F_{8,21}=$ $5.18, P<0.002, n=30$ ) revealed statistically significant differences for the main effects of trap type $\left(F_{1,21}=20.53, P=0.0002\right)$ and site $\left(F_{2,21}=7.76, P=0.003\right)$, but not for replicate $\left(F_{3,21}=0.36, P>0.78\right)$, nor for the trap type by site interaction $\left(F_{2,21}=2.14, P>0.14\right)$. Blacklight traps captured more Diptera as a proportion of total arthropods captured (mean $\pm \mathrm{SE}=$ $0.723 \pm 0.046)$ than did incandescent traps $(0.495 \pm 0.041)$ (Table 2).

Analysis of swede midge captures as a proportion of total Nematocera captured (model: $F_{8,21}=5.25, P<0.002, n=30$ ) revealed statistically significant differences for the main effects of trap type $\left(F_{1,21}=12.93, P<0.002\right)$, site $\left(F_{2,21}=7.86, P<0.003\right)$, and replicate $\left(F_{3,21}=\right.$ $3.42, P<0.04)$, but not for the trap type by site interaction $\left(F_{2,21}=1.54, P>0.20\right)$. Incandescent traps captured more swede midge as a proportion of total nematocerans $(0.111 \pm 0.037)$ than did black-light traps $(0.017 \pm 0.007)$. 
Fig. 2. Captures (mean \pm SE) of adult swede midge (Contarinia nasturtii) in traps of three different types $(n=$ 15 for each). The effective trapping period was $11 \mathrm{~h}$ for CDC light traps and $168 \mathrm{~h}$ for sticky yellow cards. Square root transformed means are presented and data from three sites are pooled. Bars with the same letter are not significantly different (Tukey's Studentized range (HSD) tests, $\alpha=0.05$ ).

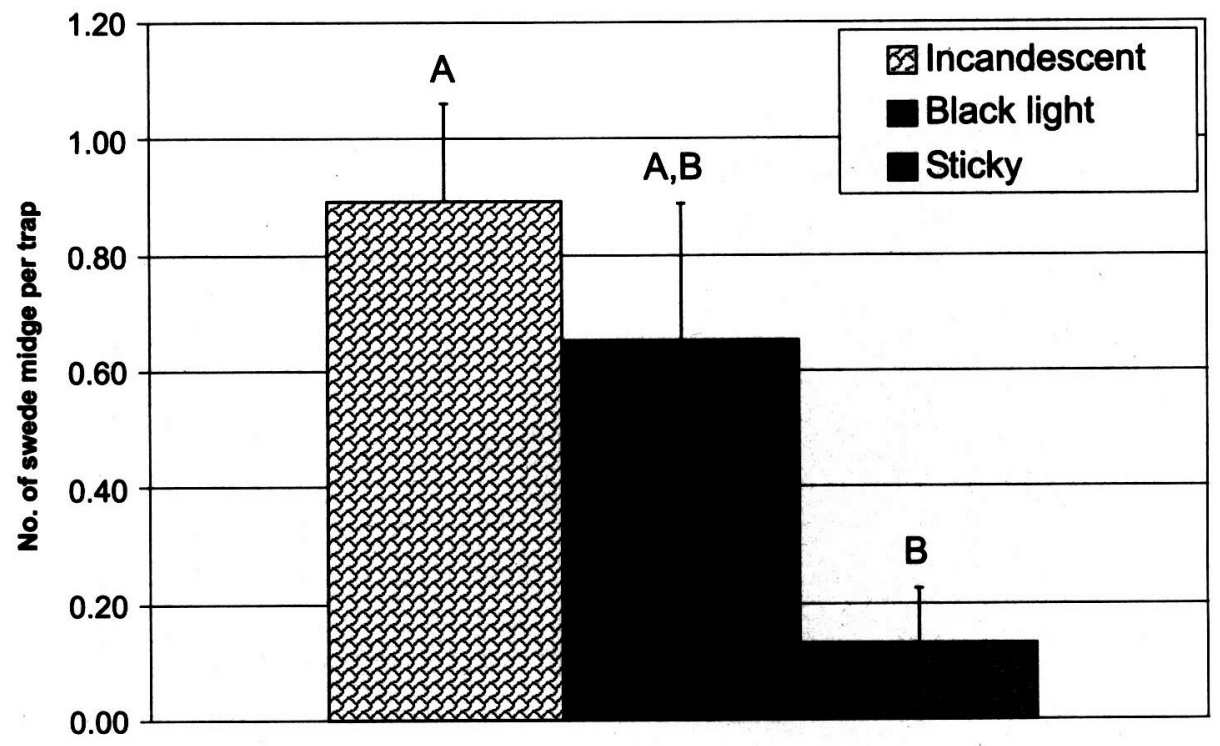

Analysis of swede midge captures as a proportion of swede midge-like specimens captured (model: $F_{8,20}=4.98, P<0.002, n=29$ ) revealed statistically significant differences for the main effects of trap type $\left(F_{1,20}=7.62, P<0.015\right)$ and site $\left(F_{2,20}=9.36, P<0.002\right)$ and for the trap type by site interaction $\left(F_{2,20}=5.38, P<0.015\right)$, but not for replicate $\left(F_{3,20}=0.91, P>0.45\right)$. Further analyses for each site separately revealed significant differences in trap type at Hillsburgh (model: $F_{3,5}=10.96, P<0.015, n=9$ ) but not at Stouffville (model: $F_{3,6}=1.43, P>0.30, n=10$ ) or Markham (model: $F_{3,6}=1.48, P>0.30, n=$ 10 ), where there were no significant main or interaction effects for trap type and replicate. At Hillsburgh, incandescent traps captured more swede midge as a proportion of total swedè midge-like individuals than did black-light traps $\left(F_{1,5}=24.06, P<0.005\right)$. An as yet unidentified midge species, which can be distinguished from Contarinia spp. by the presence of onesegmented, separated, and freely articulating cerci on the abdomen (Gagné 1981), made up most of the balance of captures of swede midgelike nematocerans.

\section{Comparison of pheromone and emergence traps}

At Markham and Stouffville the first swede midge captures in emergence traps occurred in late May to early June and the last captures in mid to late September (Table 3). Swede midge captures began and ended earlier at Stouffville than at Markham. At both sites emergence traps captured swede midge earlier than did pheromone traps (Table 3).

Captures in emergence traps maintained over bare soil (plot A) indicate that the overwintered generation of swede midge emerged in more than one peak (Figs. 3, 4a, 5a). In 2003, the first emergence peak of overwintered swede midge occurred in late spring (mid to late June) and there was continuous, but low, emergence until mid-July (Fig. 3). A second emergence peak of overwintered swede midge occurred in late summer (early to mid-August). In 2004, three distinct emergence peaks of overwintered swede midge were seen (early June, late June, and midJuly) and low captures continued through to late summer (mid-August) (Figs. 4a, 5a).

Emergence-trap captures from Markham and Stouffville indicate that there were five peak emergence events for swede midge each year (Figs. 3-5), occurring, on average, 16 days apart (Table 4). At Markham, the first three peak emergence events in 2004 (31 May, 14 June, and 30 June) from the emergence and pheromone traps were similar; however, the peak of emergence-trap captures observed on 19 July was not detected with the pheromone 


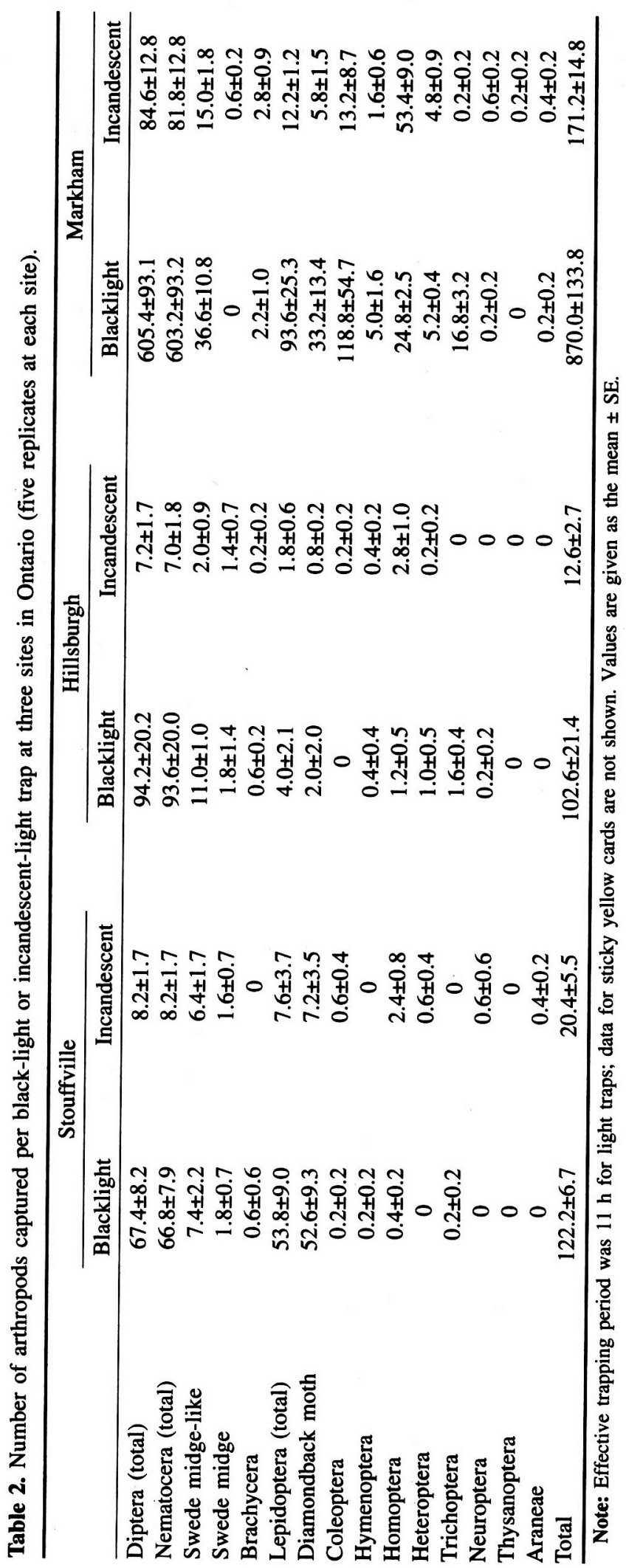

C 2007 Entomological Society of Canada 
Table 3. First and last captures of adult swede midge (Contarinia nasturtii) in emergence and pheromone traps at Markham and Stouffille, Ontario, in 2003 and 2004.

\begin{tabular}{|c|c|c|c|c|}
\hline & \multicolumn{2}{|c|}{ Markham } & \multicolumn{2}{|c|}{ Stouffville } \\
\hline & 2003 & 2004 & 2003 & 2004 \\
\hline \multicolumn{5}{|l|}{ Emergence traps } \\
\hline First capture & 7 June & 26 May & 27 May & 21 May \\
\hline Last capture & 17 Sept. & 27 Sept. & 17 Sept. & 16 Sept. \\
\hline \multicolumn{5}{|l|}{ Pheromone traps } \\
\hline First capture & - & 31 May & - & 26 May \\
\hline Last capture & - & 5 Oct. & - & 14 Oct. \\
\hline
\end{tabular}

traps, though the 11 August peak was (Fig. 4b). At Stouffille, captures in the pheromone traps were very high in 2004 , and discrete population peaks could not be easily detected (Fig. $5 b$ ). However, five peak emergence events (26 May, 11 June, 30 June, 19 July, 2 August) were observed with emergence traps.

Emergence traps captured a total of 2847 and 1580 adult swede midge in 2003 and 2004, respectively. In 2004 a total of 13997 adult males were captured in pheromone traps. At Markham the mean total count for emergence traps $(90 \pm$ 38.1) was significantly lower than for pheromone traps $(1,012 \pm 309.1)$ (Welch's test, $F_{1,2}=26.5, P=0.03$ ). Similarly, at Stouffiville the mean total count for emergence traps (117 \pm 44.7) was significantly lower than for pheromone traps $(3,653 \pm 969.8)$ (Welch's test, $F_{1,2}=39.85, P=0.02$ ).

\section{Discussion}

Swede midge captures by means of sticky yellow cards are low even at high population densities. Mean captures of 0.5-3 midges per week on sticky yellow cards are typical for sites with high swede midge populations (Hallett and Heal 2001; R.H. Hallett, unpublished data for 2001-2003). CDC light traps with incandescent bulbs were more effective than sticky yellow cards at capturing swede midge, captures being nearly an order of magnitude higher. If differences in the number of effective trapping hours are taken into consideration, black-light and incandescent CDC traps were 100 times more effective than sticky traps.

Black-light traps captured a higher proportion of Diptera than did incandescent traps, but incandescent traps were more selective than black-light traps in capturing adult swede midge versus other types of nematocerans.
Incandescent-trap samples thus required less time for sorting prior to identification. In addition, the efficiency of sorting swede midge from swede midge-like nematocerans was increased at one site (Hillsburgh), where proportionally more swede midge than other swede midge-like nematocerans were captured in incandescent traps than black-light traps. However, this further advantage of incandescent over black-light traps was not observed at the other two sites, presumably because of local differences in nematoceran diversity and abundance. White lamps $(390-770 \mathrm{~nm})$ in CDC traps have been found to be more effective than lamps of other colours, including violet (390$430 \mathrm{~nm}$ ), in capturing the chironomid Chironomus salinarius Kieffer (Ali et al. 1994). However, ultraviolet lights are most attractive to house flies (Pickens and Thimijan 1986; Roberts et al. 1992).

Total insect captures in CDC traps varied greatly among sites, likely because of factors arising from trapping on different days, as well as differences in location. Lower total insect captures at Stouffville than at Markham may be explained by lower insect flight activity due to lower minimum temperatures during the lighttrapping period and (or) to very bright moon conditions at Stouffville compared with Markham, where there was a small crescent moon that set early on the night of trapping (Table 3). The light intensity of the CDC traps relative to the night sky may also have been reduced during the gibbous moon, thus reducing their attraction to insects. Light-trap captures of mosquitoes (Janousek and Olson 1994) and arctiid and noctuid moths (Kiss et al. 1981; Vaishampayan and Verma 1983; Yela and Holyoak 1997) decrease with increasing fullness of the moon. However, moon phase did not significantly affect light-trap captures of a psychodid fly (Brinson et al. 1992) 
Fig. 3. Mean numbers of swede midge (Contarinia nasturtii) captured in emergence traps from plots with bare soil and vegetation cover at Markham (A) and Stouffville (B) in 2003.
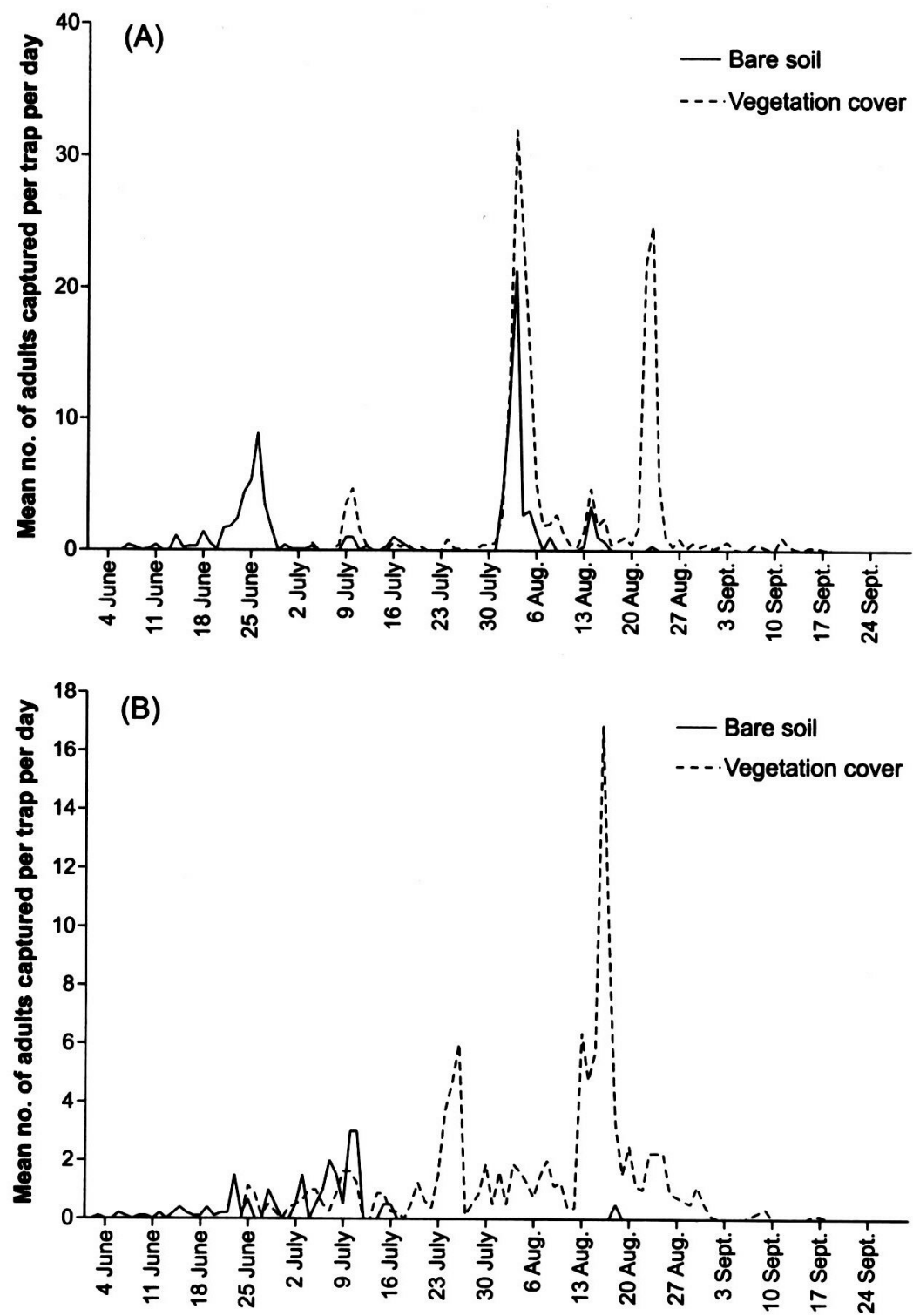

or a variety of beneficial insects (ladybeetles (Coleoptera: Coccinellidae), damsel bugs (Hemiptera: Nabidae), Ophion Fabricius sp. (Hymenoptera: Ichneumonidae), Chrysopa Leach spp. (Neuroptera: Chrysopidae), Hemerobius L. spp. (Neuroptera: Hemerobiidae), and Narvesus carolinensis Stål) (Hemiptera: Reduviidae) (Nabli et al. 1999).

Despite low total insect numbers at Stouffville in 2002, swede midge captures were relatively high at Stouffville, whereas very few swede midge were captured at Markham Season-long monitoring with sticky yellow cards at both these sites (unpublished data) indicated that the experimental period at Stouffville partially coincided with a peak of swede midge emergence, whereas by early September swede midge emergence was very low. Thus, low captures of swede midge at Markham indicate a lack of adult swede midge, rather than poor trap efficiency, during the experimental period.

Light traps are more expensive and cumbersome to erect and maintain than sticky traps, but are much more effective at capturing swede 
Fig. 4. (A) Mean numbers of swede midge (Contarinia nasturtii) captured in emergence traps from plots with bare soil and vegetation cover. (B) Log cumulative captures of male and female swede midge from emergence traps and males from pheromone traps at Markham in 2004.
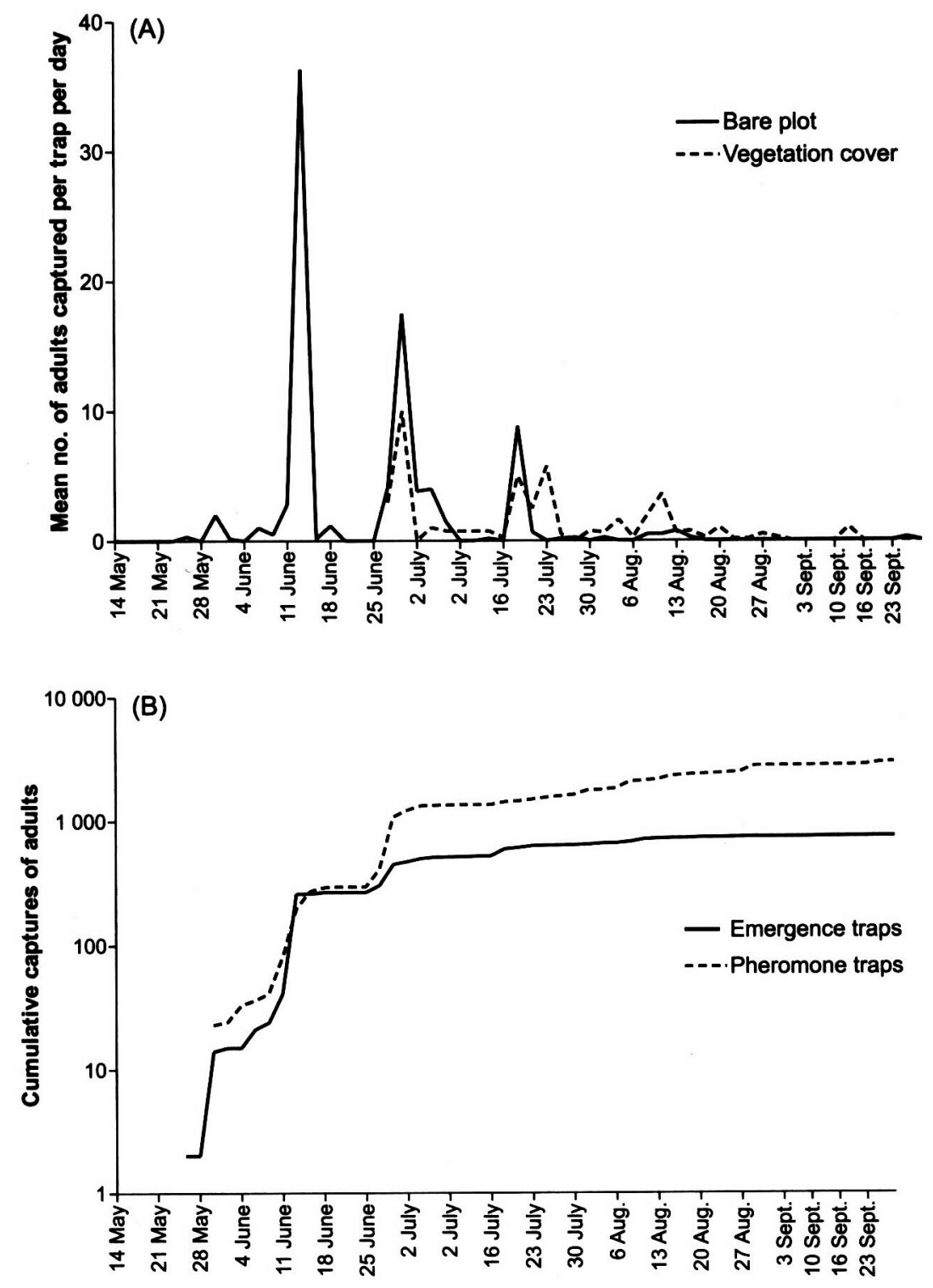

midge. In addition, $\mathrm{CDC}$ traps capture specimens in mesh bags, resulting in higher quality specimens that can be mounted or preserved in ethanol, and causing fewer problems with identification than specimens captured in sticky traps do. Incandescent CDC traps are thus recommended over the other trap types for detecting swede midge if pheromone traps are unavailable.

Two or three peaks in emergence of overwintered swede midge occurred in the populations studied (Figs. 3-5). In Norway, adults of the overwintered generation of swede midge emerge from late May to mid-August (Rygg and Braekke 1980). For some species, a multimodal adult-emergence pattern may be advantageous as a bet-hedging strategy at the population level, as reproductive individuals will emerge into the environment during several time periods, thus minimizing the risk that all individuals will emerge during times of poor environmental conditions or low host availability (Biron 
Fig. 5. (A) Mean numbers of swede midge (Contarinia nasturtii) captured in emergence traps from plots with bare soil and vegetation cover. (B) Log cumulative captures of male and female swede midge from emergence traps and males from pheromone traps at Stouffville in 2004.
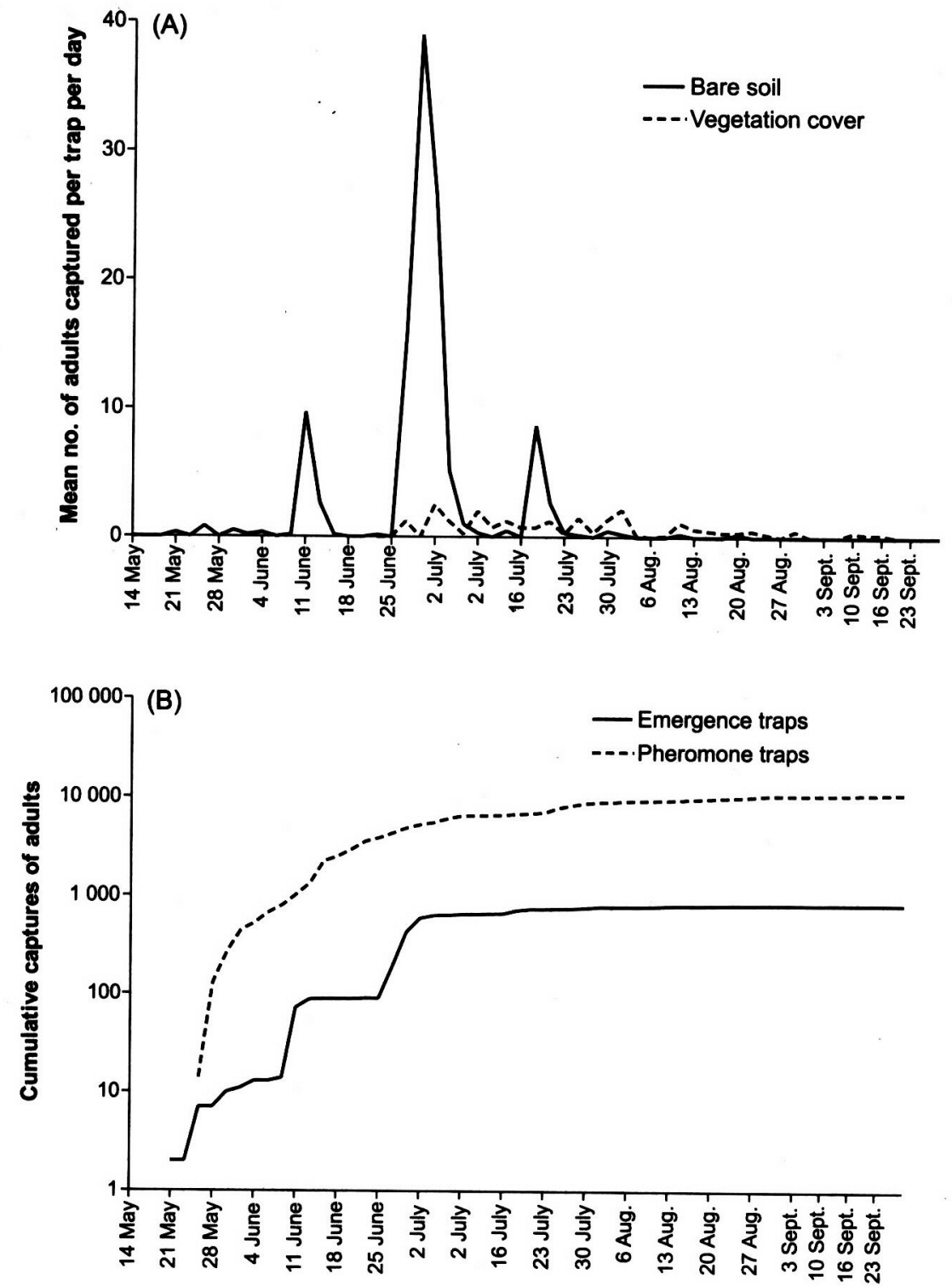

et al. 1998). Multimodal emergence patterns have also been documented in the cabbage root fly, Delia radicum (L.) (Diptera: Anthomyiidae), which has a bimodal distribution of adult spring emergence, with the relative abundance of earlyand late-emerging phenotypes varying among sites (Finch and Collier 1983; Finch et al. 1986; Walgenbach et al. 1993; Turnock and Boivin 1997; Biron et al. 1998). Knowledge of seasonal activities, including emergence patterns of a pest species, is required for better timing of control strategies (Bracken 1988). Directing control efforts at the emerging overwintered swede midge population is recommended in order to minimize population growth and maintain subsequent generations below damaging levels (Taylor 1912; Rogerson 1963), but will be complicated by emergence of the overwintered population at several points in the season.

In Europe, adult swede midge emerge in two to five, often overlapping, events per year (Taylor 1912; Dry 1915; Readshaw 1961; Rogerson 
Table 4. Observed adult swede midge (Contarinia nasturtii) emergence events, as indicated by peaks in emergence-trap captures and the number of days between successive emergence events, at Stouffville and Markham in 2003 and 2004.

\begin{tabular}{|c|c|c|c|c|}
\hline \multirow[b]{2}{*}{$\begin{array}{l}\text { Year and } \\
\text { emergence event }\end{array}$} & \multicolumn{2}{|c|}{ Markham } & \multicolumn{2}{|c|}{ Stouffville } \\
\hline & $\begin{array}{l}\text { Date of peak } \\
\text { captures }\end{array}$ & $\begin{array}{c}\text { No. of days } \\
\text { between peaks }\end{array}$ & $\begin{array}{c}\text { Date of peak } \\
\text { captures }\end{array}$ & $\begin{array}{c}\text { No. of days } \\
\text { between peaks }\end{array}$ \\
\hline \multicolumn{5}{|l|}{2003} \\
\hline 1 & 26 June & - & 23 June & - \\
\hline 2 & 10 July & 14 & 10 July & 17 \\
\hline 3 & 4 Aug. & 25 & 26 July & 16 \\
\hline 4 & 14 Aug. & 10 & 16 Aug. & 21 \\
\hline 5 & 23 Aug. & 9 & 25 Aug. & 9 \\
\hline \multicolumn{5}{|l|}{2004} \\
\hline 1 & 31 May & - & 26 May & - \\
\hline 2 & 14 June & 14 & 11 June & 16 \\
\hline 3 & 30 June & 16 & 30 June & 19 \\
\hline 4 & 19 July & 19 & 19 July & 19 \\
\hline 5 & 11 Aug. & 23 & 2 Aug. & 14 \\
\hline
\end{tabular}

1963), which may represent different generations and (or) emergence phenotypes. Readshaw (1961) reported the swede midge lifespan to be 19-82 days at $30-12{ }^{\circ} \mathrm{C}$; based on these developmental periods, Ontario emergence events also appear to overlap (Table 4). With up to five (Figs. 3-5) overlapping emergence events of swede midge occurring in Ontario each year, population numbers can build up rapidly. These emergence events may represent distinct generations of swede midge, multimodal emergence (as discussed above), or a continuous emergence pattern. Adult swede midge are present in the field from May to October, which means that in infested areas, any cole crops, regardless of planting date, may serve as oviposition sites and as hosts for developing larvae. A single crop planting may provide hosts to several generations of swede midge, particularly crops such as broccoli and cauliflower, where all growth stages are vulnerable to attack (Barnes 1946).

First captures of swede midge occurred slightly later in pheromone traps than in emergence traps. Captures at Stouffville were very high, so discrete emergence peaks could not easily be determined. At Markham, despite the 5 day lag before the first swede midge captures in May, seasonal trends in population peaks were similar for emergence and pheromone traps until early July. The additional peaks delimited by the pheromone traps are not likely to be emergence events. With overlapping generations, it is expected that as the season progresses the pheromone traps no longer reflect the discrete emergence events evident with emergence traps. Despite the lack of clarity late in the season in reflecting swede midge emergence, pheromone traps appear to be a reliable alternative to emergence traps as a population-monitoring tool.

Monitoring of the pest organism is a key component of any integrated pest management program (Pedigo 2002). The choice of monitoring tools depends on how the resulting information will be used. If monitoring data will be utilized for timing control measures, the sampling tool must provide an accurate prediction of the target population, whereas for monitoring population growth, it must reflect the population dynamics of the target population (Hutchins 1994). Emergence traps are better suited for monitoring population dynamics than are pheromone traps because emergence-trap captures clearly indicate when adult swede midge emergence events occur. Pheromone traps, which reflect flight activity of both newly emerged and older males, are better suited than emergence traps for obtaining rapid population estimates to be used in timing insecticide treatments. Pheromone traps capture more swede midge than emergence traps and are more selective in capturing insects, therefore little processing time is required to identify the flies captured in pheromone traps. Pheromone traps are small, portable, and easy to maintain; growers are able to till, fertilize, scuffle, and apply insecticide treatments in fields with pheromone traps in place without having to remove the traps from the field. While they are suitable for 
research purposes and for monitoring swede midge population dynamics, emergence traps are not recommended for use by growers. Based on the magnitude of swede midge captures, pheromone traps are also well suited for use in detecting the presence and abundance of swede midge.

\section{Acknowledgments}

The authors thank D. Almas, D. Defilippis, J. Hulshof, and J. Wilson for field research sites, Dr. S.A. Marshall for emergence-trap materials and design, and S. McAlister, C. Sopher, R. Gorman, and N. Stoddard for field assistance. This research was funded in part by the CanadaOntario R\&D Fund, the Ontario Ministry of Agriculture, Food and Rural Affairs (OMAFRA) Special Research Fund, and the OMAFRA University of Guelph Plants Program.

\section{References}

Ali, A., Ceretti, G., Barbato, L., Marchese, G., D'Andrea, F., and Stanley, B. 1994. Attraction of Chironomus salinarius (Diptera: Chironomidae) to artificial light on an island in the saltwater lagoon of Venice, Italy. Journal of the American Mosquito Control Association, 10: 35-41.

Barnes, H.F. 1946. Gall midges of economic importance. Vol. 1. Gall midges of root and vegetable crops. Crosby Lockwood and Son Ltd., London, United Kingdom.

Biron, D., Langlet, X., Boivin, G., and Brunel, E. 1998. Expression of early and late-emerging phenotypes in both diapausing and non-diapausing Delia radicum L. pupae. Entomologia Experimentalis et Applicata, 87: 119-124.

Bowley, S.R. 1999. A hitchhiker's guide to statistics in plant biology. Any Old Subject Books, Guelph, Ontario.

Bracken, G.K. 1988. Seasonal occurrence and infestation potential of cabbage maggot, Delia radicum (L.) (Diptera: Anthomyiidae), attacking rutabaga in Manitoba as determined by captures of females in water traps. The Canadian Entomologist, 120: 609-614.

Brinson, F.J., Hagan, D.V., Comer, J.A., and Strohlein, D.A. 1992. Seasonal abundance of Lutziomyia shannoni (Diptera: Psychodidae) on Ossabaw Island, Georgia. Journal of Medical Entomology, 29: 178-182.

Canadian Food Inspection Agency. 2002. Plant health risk assessment: Contarinia nasturtii (Kieffer), the swede midge. PHPD Request: 200204; File No. 31403. Plant Health Risk Assessment Unit, Canadian Food Inspection Agency, Nepean, Ontario.
Dry, F.W. 1915. An attempt to measure the local and seasonal abundance of the swede midge in parts of Yorkshire over the years 1912 to 1914. The Annals of Applied Biology, 2: 81-108.

Finch, S., and Collier, R.H. 1983. Emergence of flies from overwintering populations of cabbage root fly pupae. Ecological Entomology, 8: 29-36.

Finch, S., Collier, R.H., and Skinner, G. 1986. Local population differences in emergence of cabbage root flies from south-west Lancashire: implications for pest forecasting and population divergence. Ecological Entomology, 11: 139-145.

Gagné, R.J. 1981. Cecidomyiidae. In Manual of Nearctic Diptera. Vol. 1. Monograph No. 27. Edited by J.F. McAlpine, B.V. Peterson, G.E. Shewell, H.J. Teskey, J.R. Vockeroth, and D.M. Wood. Research Branch, Agriculture Canada, Ottawa, Ontario. pp. 257-292.

Hallett, R.H., and Heal, J.D. 2001. First Nearctic record of the swede midge (Diptera: Cecidomyiidae), a pest of cruciferous crops from Europe. The Canadian Entomologist, 133: 713-715.

Harris, K.M. 1966. Gall midge genera of economic importance (Diptera: Cecidomyiidae). Part I. Introduction and subfamily Cecidomyiinae; supertribe Cecidomyiidi. Transactions of the Royal Entomological Society of London, 118(10): 313-358.

Hill, D.S. 1987. Agricultural insect pests of temperate regions and their control. Cambridge University Press, Cambridge, United Kingdom.

Hillbur, Y., Celander, R., Baur, R., Rauscher, S., Haftmann, J., Franke, S., and Francke, W. 2005. Identification of the sex pheromone of the swede midge, Contarinia nasturtii. Journal of Chemical Ecology, 31: 1807-1828.

Hutchins, S.H. 1994. Techniques for sampling arthropods in integrated pest management. In Handbook of sampling methods for arthropods in agriculture. Edited by L.P. Pedigo and G.D. Buntin. CRC Press, Boca Raton, Florida. pp. 73-98.

Janousek, T.E., and Olson, J.K. 1994. Effect of lunar eclipse on the flight activity of mosquitoes in the upper Gulf coast of Texas. Journal of the American Mosquito Control Association, 10: 222-224.

Kiss, M., Ekk, I., Toth, G., Szabo, S., and Nowinsky, L. 1981. Common effects of geomagnetism and change of moon phases on light-trap catches of fall webworm moths (Hyphantria cunea Drury). Zeitschrift für angewandte Entomologie, 91: 403-411.

Marshall, S.A., and Cui, Y.S. 2005. Systematics of Robustagramma, a new genus of New World Sphaeroceridae (Diptera). Zootaxa, 1026: 1-122.

Nabli, H., Bailey, W.C., and Necibi, S. 1999. Beneficial insect attraction to light traps with different wavelengths. Biological Control (Theory and Applications in Pest Management), 16: 185-188.

Pedigo, L. 2002. Entomology and pest management. 4th ed. Prentice Hall, Englewood Cliffs, New Jersey. 
Pickens, L.G., and Thimijan, R.W. 1986. Design parameters that affect the performance of UVemitting traps in attracting house flies (Diptera: Muscidae). Journal of Economic Entomology, 79: 1003-1009.

Readshaw, J.L. 1961. The biology and ecology of the swede midge, Contarinia nasturtii (Kieffer) (Diptera; Cecidomyiidae). Ph.D. thesis, University of Durham, Durham, United Kingdom.

Roberts, A.E., Syms, P.R., and Goodman, L.J. 1992. Intensity and spectral emission as factors affecting the efficacy of an insect electrocutor trap towards the house-fly. Entomologia Experimentalis et Applicata, 64: 259-268.

Rogerson, J.P. 1963. Swede midge on two Northumberland farms, 1959-61. Plant Pathology, 12: $161-171$.

Rygg, T.D., and Braekke, H.P. 1980. Swede midge (Contarinia nasturtii Kieffer) (Diptera, Cecidomyiade): investigations on biology, symptoms of attack and effects on yield. Meldinger fra Norges landbrukshøgskole, 59: 1-9.

SAS Institute Inc. 2001. The SAS ${ }^{\bowtie}$ system for Windows. Release 8.02. SAS Institute Inc., Cary, North Carolina.

Taylor, T.H. 1912. Cabbage-top in swedes. Rep. No. 82, Yorkshire Council for Agric. Educ., University of Leeds, Leeds, United Kingdom.
Turnock, W.J., and Boivin, G. 1997. Inter- and intrapopulation differences in the effects of temperature on postdiapause development of Delia radicum. Entomologia Experimentalis et Applicata, 84: 255265.

United States Department of Agriculture. 2002. Canada - Agricultural situation - plant health measures to limit spread of swede midge. Global Agriculture Information Network (GAIN) Rep. CA2068, Foreign Agricultural Service, United States Department of Agriculture.

Vaishampayan, S.M., and Verma, R. 1983. Effect of moon phase and lunar periodicity on the light trap catches of gram pod borer moths Heliothis armigera (Hubner). In Insect interrelations in forest and agro ecosystems. Edited by P.K. SenSarma, S.K. Kulshrestha, and S.K. Sangal. Jugal Kishore \& Co., Dehra Dun, India. pp. 123-130.

Walgenbach, J.F., Eckenrode, C.J., and Straub, R.W. 1993. Emergence patterns of Delia radicum (Diptera: Anthomyiidae) populations from North Carolina and New York. Environmental Entomology, 22: 559-566.

Yela, J.L., and Holyoak, M. 1997. Effects of moonlight and meterological factors on light and bait trap catches of noctuid moths (Lepidoptera: Noctuidae). Environmental Entomology, 26: 1283-1290. 